\title{
Simultaneous Estimation of Saxagliptin and Dapagliflozin in Human Plasma by Validated High Performance Liquid Chromatography - Ultraviolet Method
}

\author{
Saksagliptin ve Dapagliflozin Tarafından Doğrulanmış Yüksek Performanslı \\ Sıvı Kromatografi - Ultraviyole Yöntemi İnsan Plazma Eş Zamanlı Tahmin
}

\author{
(D) Sharmila DONEPUDI ${ }^{1}$, (D) Suneetha ACHANTA2* \\ IV.V. Institute of Pharmaceutical Sciences, Department of Pharmaceutical Analysis, Andhra Pradesh, India \\ 2 Hindu College of Pharmacy, Department of Pharmaceutical Analysis, Andhra Pradesh, India
}

\begin{abstract}
Objectives: The fixed dose combination of saxagliptin and dapagliflozin is a recently approved antidiabetic medication. It is marketed under the brand name Qtern. The aim of this study was to develop a simple, rapid, sensitive, and validated isocratic reversed phase-high performance liquid chromatography (RP-HPLC) method for the simultaneous estimation of saxagliptin and dapagliflozin in human plasma using linagliptin as internal standard as per US-Food and Drug Administration guidelines.

Materials and Methods: The method was performed on a Waters 2695 HPLC equipped with a quaternary pump. The analyte separation was achieved using an Eclipse XDB C18 $(150 \times 4.6 \mathrm{~mm} \times 5 \mu \mathrm{m})$ column with a mobile phase consisting of $0.1 \%$ ortho phosphoric acid and acetonitrile (50:50) with $\mathrm{pH}$ adjusted to 5.0 at $1 \mathrm{~mL} / \mathrm{min}$ flow rate.

Results: The analyte was detected at $254 \mathrm{~nm}$. The retention time of the internal standard, saxagliptin, and dapagliflozin was $2.746,5.173$, and 7.218 $\mathrm{min}$, respectively. The peaks were found to be free of interference. The method was validated over a dynamic linear range of 0.01 to $0.5 \mu \mathrm{g} / \mathrm{mL}$ and 0.05 to $2 \mu \mathrm{g} / \mathrm{mL}$ for saxagliptin and dapagliflozin, respectively, with a correlation coefficient of 0.998 . The precision and accuracy of samples of six replicate measurements at lower limits of quantification level were within the limits. The analytes were found to be stable in human plasma at $-28^{\circ} \mathrm{C}$ for 37 days.

Conclusion: The stability, sensitivity, specificity, and reproducibility of this method make it appropriate for the determination of saxagliptin and dapagliflozin in human plasma.

Key words: Saxagliptin, dapagliflozin, linagliptin, human plasma, isocratic

öz

Amaç: Saksagliptin ve dapagliflozinin sabit doz kombinasyonu antidiyabetik ilaç tedavisi için onaylanmıştır ve Qtern markası ile pazarda yer almaktadır. Bu çalışmada amaç, insan plazmasındaki saksagliptin ve dapagliflozinin eş zamanlı tayini için Avrupa Gıda ve İlaç İdaresi kılavuzlarına uygun şekilde linagliptin iç standardı kullanarak ve basit, hızlı, hassas ve validasyonu yapılmış izokroatik ters faz-yüksek performanslı sıvı kromatografi (RP-HPLC) yöntemi geliştirmektir.

Gereç ve Yöntemler: Method 4'lü akış pompasına sahip Waters 2695 marka HPLC cihazı ile gerçekleştirilmiştir. Analitin ayrılmasında Eclipse XDB C18 kolon $(150 \times 4.6 \mathrm{~mm} \times 5 \mu \mathrm{m})$ kullanılmıştır. Kullanılan mobil fazın bileşimi ise pH 5.0 ayarlanmış \%0.1 orto fosforik asit ve asetonitril (50:50) şeklinde olup akış hızı analiz süresince $1 \mathrm{~mL} / \mathrm{dk}$ 'dır.

Bulgular: Analit 254 nm'de tayin edilmiştir. İç standart, saksagliptin ve dapagliflozinin alıkonma zamanları sırasıyla $2.746,5.173$ ve 7.218 dk olarak tespit edilmiştir. Pikler interferanslar gözlenmeden elde edilmiştir. Metot validasyonu saksagliptin ve dapagliflozin için sırasıyla 0.01 ile $0.5 \mu \mathrm{g} / \mathrm{mL}$ ve 0.05 ile $2 \mu \mathrm{g} / \mathrm{mL}$ doğrusal derişim aralığında 0.998 korelasyon katsayısı ile gerçekleştirilmiştir. Numunlere ait 6 ölçüme ait kesinlik ve doğruluk tayin sınırları içerisinde bulunmuştur. Analitlerin insan plazması içinde $-28^{\circ} \mathrm{C}$ sıcaklıkta 37 gün boyunca kararlı halde kaldığı belirlenmiştir.
\end{abstract}

*Correspondence: E-mail: drasuneetha@gmail.com, ORCID-ID: orcid.org/0000-0002-9793-7937

Received: 01.04.2018, Accepted: 25.04.2018

๑Turk J Pharm Sci, Published by Galenos Publishing House. 
Sonuç: Bu yönteme ait elde edilen kararlılık, duyarlılı, özgüllük ve tekrarlanabilirlik sonuçları, geliştirilen bu yöntemin insan plazmasında saksagliptin ve dapagliflozinin belirlenmesi için uygun olduğunu ortaya koymuştur.

Anahtar kelimeler: Saksagliptin, dapagliflozin, linagliptin, insan plazma, izokratik

\section{INTRODUCTION}

The combination of saxagliptin and dapagliflozin has the potential to confer significant benefits in glycaemic control without the risk of weight gain and hypoglycemia, which may be associated with other medications used to treat type 2 diabetes.' The fixed dose combination containing $10 \mathrm{mg}$ of dapagliflozin and $5 \mathrm{mg}$ of saxagliptin was recently approved by the US-Food and Drug Administration (FDA) for adults with type-2 diabetes. The combination was available under the brand name Qtern. ${ }^{2}$ Dapagliflozin belongs to the sodium glucose co-transporter-2 inhibitors with the chemical name (2S,3R,4R,5S,6R)-2-[4-chloro-3-(4-ethoxybenzyl)phenyl]-6(hydroxymethyl) tetrahydro-2H-pyran-3,4,5-triol (Figure 1a). . $^{3-6}$

Saxagliptin belongs to the class of drugs inhibiting the enzyme dipeptidyl-peptidase-4. This class of compound works by stimulating glucose-dependent insulin release. Chemically, it is (1S,3S,5S)-2-((2S)-amino(3-hydroxytricyclo(3.3.1.13,7)dec-1yl)acetyl)-2-azabicyclo(3.1.0) hexane-3-carbonitrile (Figure 1b) and has the molecular formula $\mathrm{C}_{18} \mathrm{H}_{25} \mathrm{~N}_{3} \mathrm{O}_{2}{ }^{7-9} \mathrm{~A}$ review of the literature revealed that a few analytical methods like LC-Mass spectrometry, ${ }^{10,11}$ HPLC, 12-19 and spectroscopic methods ${ }^{20,21}$ are available for the estimation of these drugs, either individually or in combination with other diabetic drugs like metformin.22-26 The present work aimed to develop a simple, rapid, and accurate method for the estimation of dapagliflozin and saxagliptin in human plasma, as per US-FDA guidelines. ${ }^{27}$ Moreover, the present method is the first for the estimation of this combination in a biological matrix.

\section{MATERIALS AND METHODS}

\section{Reagents and chemicals}

The pure drug samples of saxagliptin and dapagliflozin were purchased from Selleckchem.com LLC, supplied by Pro Lab Marketing. HPLC grade acetonitrile, HPLC grade methanol, and all other chemicals were obtained from Merck Chemical Division, Mumbai. HPLC grade water obtained from the Milli-Q water purification system was used throughout the study.

\section{Instrumentation}

Chromatography was performed with a Waters 2695 HPLC provided with a quaternary pump, auto-sampler, column oven, degasser, and 2996 PDA detector and with Empower-2 software.

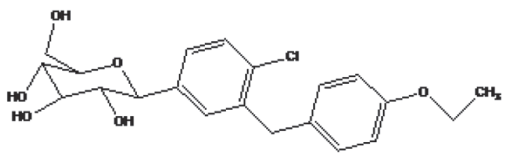

(a)

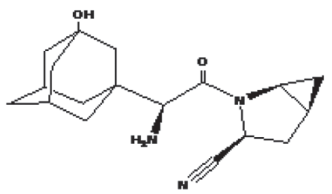

(b)
Figure 1. Chemical structure of a) dapagliflozin and b) saxagliptin

\section{Chromatographic conditions}

The separation was achieved by isocratic elution using an Eclipse XDB C18 column $(150 \times 4.6 \mathrm{~mm} \times 5 \mu \mathrm{m})$ with a mobile phase consisting of $0.1 \%$ orthophosphoric acid and acetonitrile (50:50) with $\mathrm{pH}$ adjusted to 4.5. The separation was achieved within $10 \mathrm{~min}$ at $254 \mathrm{~nm}$ using a $1 \mathrm{~mL} / \mathrm{min}$ flow rate. The sample dilution was carried out using water:acetonitrile (50:50 ratio) as diluent.

\section{Preparation of internal standard}

The working internal standard was prepared by transferring 10 $\mathrm{mg}$ of linagliptin to a $10 \mathrm{~mL}$ volumetric flask; the final volume was completed using the diluent. From the resulting stock, 10 $\mu \mathrm{g} / \mathrm{mL}$ solution was prepared by further dilutions.

\section{Preparation of calibration and quality control solutions}

The stock solutions of saxagliptin and dapagliflozin were prepared individually by dissolving $10 \mathrm{mg}$ of the drug in $10 \mathrm{~mL}$ of diluent to obtain a $1 \mathrm{mg} / \mathrm{mL}$ concentration of each analyte. The stock solution was further diluted to prepare working standards. The calibration and quality control samples were obtained by spiking $10 \mu \mathrm{L}$ of the above-prepared solutions of each analyte into $250 \mu \mathrm{L}$ of plasma containing $50 \mu \mathrm{L}$ of the internal standard. This resulted in final concentrations of saxagliptin and dapagliflozin of $0.01 \mu \mathrm{g} / \mathrm{mL}$ to $0.50 \mu \mathrm{g} / \mathrm{mL}$ and $0.05 \mu \mathrm{g} / \mathrm{mL}$ to $2.00 \mu \mathrm{g} / \mathrm{mL}$, respectively, after spiking them into the plasma.

\section{Sample preparation and extraction}

The standard plasma samples, containing $10 \mu \mathrm{L}$ of each analyte and $50 \mu \mathrm{L}$ of internal standard $(10 \mu \mathrm{g} / \mathrm{mL})$, were mixed with 2 $\mathrm{mL}$ of acetonitrile. The sample tubes were vortexed for $2 \mathrm{~min}$ and were then centrifuged at $3200 \mathrm{rpm}$ for $3 \mathrm{~min}$. The resultant organic layer was used for analysis.

\section{Method validation}

A thorough and complete method validation was performed following the US-FDA guidelines. The method was validated for system suitability, auto-sampler carryover, specificity and screening of the biological matrix, sensitivity, matrix effect, linearity, precision and accuracy, recovery of the analyte and internal standard, ruggedness, reinjection reproducibility, and stability. The stability studies included bench top, freeze-thaw, and long-term stability at $-28^{\circ} \mathrm{C}$ and $-80^{\circ} \mathrm{C}$.

\section{Specificity}

Specificity of the biological matrix was assessed and screening was performed using six blank standards and lower limit of quantification (LLOQ) level samples. All of the samples were checked to determine the extent of interference by the plasma components with the analyte and internal standard.

\section{Calibration curve}

The linearity of the method was determined by analysis of the standard plots associated with an eight-point standard 
calibration curve. Eight concentrations of saxagliptin and dapagliflozin ranging from 0.01 to $0.50 \mu \mathrm{g} / \mathrm{mL}$ and 0.05 to 2.00 $\mu \mathrm{g} / \mathrm{mL}$, respectively, were used, which included the LLOQ, low quality control (LQC), medium quality control (MQC), high quality control (HQC), and upper limit of quantification (ULOQ). The calibration curve was constructed by plotting the peak area ratio of the analytes to the internal standard against standard concentrations. The percentage difference of back-calculated concentrations to the nominal concentration (distribution of the residuals) was determined to validate the correlation. The acceptance criterion for the calibration model applied if residuals were within $15 \%$ for all calibration levels except LLOQ. Correlation coefficient, slope, and intercept were determined to evaluate the calibration curve.

\section{Accuracy and precision}

Intraday precision and accuracy were assessed at the lower, middle, high, and lower limit of quantification quality control samples LQC, MQC, HQC, and LLOQ in six replicates for both of the analytes, while interday precision and accuracy were assessed for three consecutive days by using quality control samples. Mean values were obtained for calculated drug concentration over these batches. The accuracy of the analytical method describes the closeness of the mean test results obtained by the method to the actual value of the analyte and was determined by replicate analysis of the analyte. The accuracy and precision were calculated and expressed in terms of \% mean accuracy and coefficient of variation (\% CV), respectively.

\section{Recovery}

Recovery of the analytes from the extraction procedure was performed at LQC, MQC, and HQC levels. It was assessed by comparing the peak area of the extracted samples (spiked before extraction) to the peak area of the unextracted samples (quality control working solutions spiked in extracted plasma).

\section{Ruggedness}

Ruggedness refers to the ability of an analytical method to remain unaffected by small variations. Parameters were used to evaluate the constancy of the results when external factors such as analyst, laboratory, instrument, reagents, and days were varied. The ruggedness of the method assessed was determined using different analysts and on different instruments of the same make.

\section{Sensitivity}

Sensitivity is defined as the lowest analyte concentration that can be measured with acceptable accuracy and precision. Sensitivity experiments were carried out by using six replicates of the LLOQ level sample to determine the lowest limit of detection, the \% mean accuracy, and the \% CV.

\section{Stability}

Stability studies were performed by keeping replicates of plasma samples at room temperature for $24 \mathrm{~h}$. The freeze-thaw stability of the drugs in plasma samples was studied over three freeze-thaw cycles, by thawing at room temperature for 2-3 $\mathrm{h}$ and refreezing for 12-24 h. The stability of the drugs in plasma was also tested after storage at $-80^{\circ} \mathrm{C}$. The concentration of the drugs after each storage period was related to the initial analyte concentrations of freshly prepared samples. Samples were considered stable if the assay values were within the acceptable limits of accuracy and precision.

\section{RESULTS}

\section{Method optimization}

To obtain the best results, different mobile phase compositions containing phosphate buffer systems with varied $\mathrm{pH}$ and organic solvents like methanol and acetonitrile were used to provide adequate sensitivity and selectivity in a short separation time. The best results were obtained with the mobile phase consisting of $0.1 \%$ phosphoric acid ( $\mathrm{pH} \mathrm{4.5)}$ and acetonitrile (50:50) with a flow rate of $1 \mathrm{~mL} / \mathrm{min}$. The detection was monitored at 254 $\mathrm{nm}$. With these conditions, the retention times of linagliptin, saxagliptin, and dapagliflozin were found to be 2.784, 5.295, and $7.204 \mathrm{~min}$, respectively.

\section{Method validation}

\section{System suitability and auto-sampler carryover}

System suitability was assessed using the MQC level sample as six homogenous injections. The \% CV for retention time and response was calculated. The results are presented in Table 1. The values obtained were lower than $1 \%$, which shows

Table 1. Statistical analysis of system suitability parameters

\begin{tabular}{lllll} 
Parameter & Internal standard & Saxagliptin & Dapagliflozin & Acceptance \\
\hline Retention time $\left(t_{R}\right)$ & 0.50 & 1.07 & 0.49 & $\%$ RSD $\leq 2$ \\
\hline Area under the peak & 0.88 & 0.35 & 0.98 & $\%$ RSD $\leq 5$ \\
\hline Resolution $\left(\mathrm{R}_{\mathrm{s}}=2\left[\mathrm{t}_{\mathrm{R} 2}-\mathrm{t}_{\mathrm{R} 1}\right] /\left[\mathrm{W}_{1}-\mathrm{W}_{2}\right]\right)$ & - & 10.95 & 7.11 & $\mathrm{R}_{\mathrm{s}}>2$ \\
\hline Number of theoretical plates $\left(\mathrm{n}=16 \times\left[\mathrm{t}_{\mathrm{r}} / \mathrm{W}\right]^{2}\right)$ & 7238 & 9817 & 9758 & Increases with efficiency of the separation \\
\hline Tailing factor $(\mathrm{T})$ & 1.13 & 1.12 & 1.08 & $\mathrm{~T} \leq 2$ \\
\hline HETP $(\mathrm{H}=\mathrm{L} / \mathrm{N} \mathrm{cm} / \mathrm{plate})$ & 0.005 & 0.015 & 0.0038 & Smaller the value, higher the column efficacy \\
\hline Capacity factor $\left(\mathrm{K}^{\prime}=\left[\mathrm{t}_{\mathrm{R}}-\mathrm{t}_{\mathrm{M}}\right] / \mathrm{t}_{\mathrm{M}}\right)$ & 1.11 & 2.98 & 4.55 & $1-10$ \\
\hline
\end{tabular}

RSD: Relative standard deviation, HETP: Height equivalent of a theoretical 
the suitability of the system for the analysis of the selected combination in human plasma.

Auto-sample carryover was assessed by ULOQ and LLOQ levels to ensure that it did not affect the accuracy and precision. No carryover was observed.

\section{Linearity}

The ratio of peak area of analyte to internal standard was used for construction of the calibration curve. The linearity of saxagliptin and dapagliflozin was established by an eight-point calibration curve. The most variable regression equation of the calibration curve for saxagliptin and dapagliflozin was $y=0.126( \pm 0.02) x+$ 0.003 and $y=0.53( \pm 0.02) x-0.002$, respectively. The linearity of the calibration graph was validated by the high value of the correlation coefficient with an average value of 0.996 and 0.998 for saxagliptin and dapagliflozin, respectively. The standard curves of saxagliptin and dapagliflozin are presented in Figure 2.

\section{Precision and accuracy}

The precision and accuracy of the methods were assessed by analyzing six replicates of LLOQ, LQC, MQC, and HQC levels. The accuracy of the method was determined by calculating the \% mean accuracy and the precision by calculating relative standard deviation. The data regarding precision and accuracy are summarized in Table 2. The chromatogram of quality control samples is shown in Figure 3 . The \% mean accuracy of saxagliptin and dapagliflozin ranged from 98.33 to 101.29 and from 98.43 to 103.28 , respectively.

\section{Recovery}

Recovery of saxagliptin and dapagliflozin was determined by comparing the mean peak areas of six replicates of three quality control samples (HQC, MQC, and LQC) with the mean peak areas of unextracted quality control samples at the same level. The results of the recovery study are given in Table 3. The results are within the acceptance limits.

\section{Ruggedness}

The present method showed good ruggedness when it was performed using different analysts and on different instruments
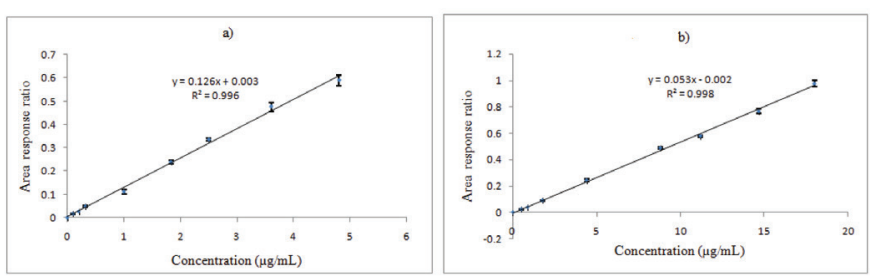

Figure 2. Standard curves of a) saxagliptin and b) dapagliflozin

Table 2. Intra- and interday precision and accuracy summary ${ }^{*} n=18$

\begin{tabular}{|c|c|c|c|c|c|c|c|c|}
\hline \multirow{2}{*}{ Added concentration $(\mu \mathrm{g} / \mathrm{mL})$} & \multicolumn{4}{|c|}{ Saxagliptin } & \multicolumn{4}{|c|}{ Dapagliflozin } \\
\hline & 0.40 & 0.02 & 0.040 & 0.010 & 1.60 & 1.00 & 0.2 & 0.050 \\
\hline \multicolumn{9}{|l|}{ Between-batch $(n=18)$} \\
\hline Mean & 0.4038 & 0.0199 & 0.0394 & 0.0098 & 1.6127 & 1.0017 & 0.2019 & 0.0496 \\
\hline SD & 0.0196 & 0.0015 & 0.0021 & 0.0008 & 0.0743 & 0.0763 & 0.0103 & 0.0037 \\
\hline$\%$ RSD & 4.85 & 7.29 & 5.31 & 7.99 & 4.61 & 7.62 & 5.12 & 6.97 \\
\hline$\% \mathrm{CV}$ & 100.94 & 99.44 & 98.61 & 98.33 & 100.79 & 100.17 & 100.95 & 99.26 \\
\hline \multicolumn{9}{|l|}{ Day $1(n=6)$} \\
\hline Mean & 0.4030 & 0.0197 & 0.0395 & 0.0098 & 1.6128 & 1.0085 & 0.2018 & 0.0493 \\
\hline SD & 0.0217 & 0.0012 & 0.0016 & 0.0008 & 0.1138 & 0.0915 & 0.0097 & 0.0037 \\
\hline$\%$ RSD & 5.40 & 6.16 & 4.16 & 7.66 & 7.05 & 9.08 & 4.83 & 7.44 \\
\hline$\% \mathrm{CV}$ & 100.75 & 98.33 & 98.75 & 98.33 & 100.80 & 100.85 & 100.92 & 98.67 \\
\hline \multicolumn{9}{|l|}{ Day $2(n=6)$} \\
\hline Mean & 0.4052 & 0.0200 & 0.0395 & 0.0098 & 1.6117 & 1.0328 & 0.2062 & 0.0492 \\
\hline SD & 0.0107 & 0.0017 & 0.0027 & 0.0008 & 0.0534 & 0.0525 & 0.0114 & 0.0029 \\
\hline$\%$ RSD & 2.65 & 8.37 & 6.93 & 7.66 & 3.31 & 5.08 & 5.52 & 5.90 \\
\hline$\% \mathrm{CV}$ & 101.29 & 100.00 & 98.75 & 98.33 & 100.73 & 103.28 & 103.10 & 98.43 \\
\hline \multicolumn{9}{|l|}{ Day $3(n=6)$} \\
\hline Mean & 0.4032 & 0.0200 & 0.0393 & 0.0098 & 1.6135 & 0.9637 & 0.1977 & 0.0503 \\
\hline SD & 0.0267 & 0.0017 & 0.0022 & 0.0010 & 0.0545 & 0.0755 & 0.0098 & 0.0042 \\
\hline$\%$ RSD & 6.61 & 8.37 & 5.49 & 10.00 & 3.38 & 7.83 & 4.94 & 8.40 \\
\hline$\% \mathrm{CV}$ & 100.79 & 100.00 & 98.33 & 98.33 & 100.84 & 96.37 & 98.83 & 100.67 \\
\hline
\end{tabular}

SD: Standard deviation, RSD: Relative standard deviation, CV: Coefficient of variation 

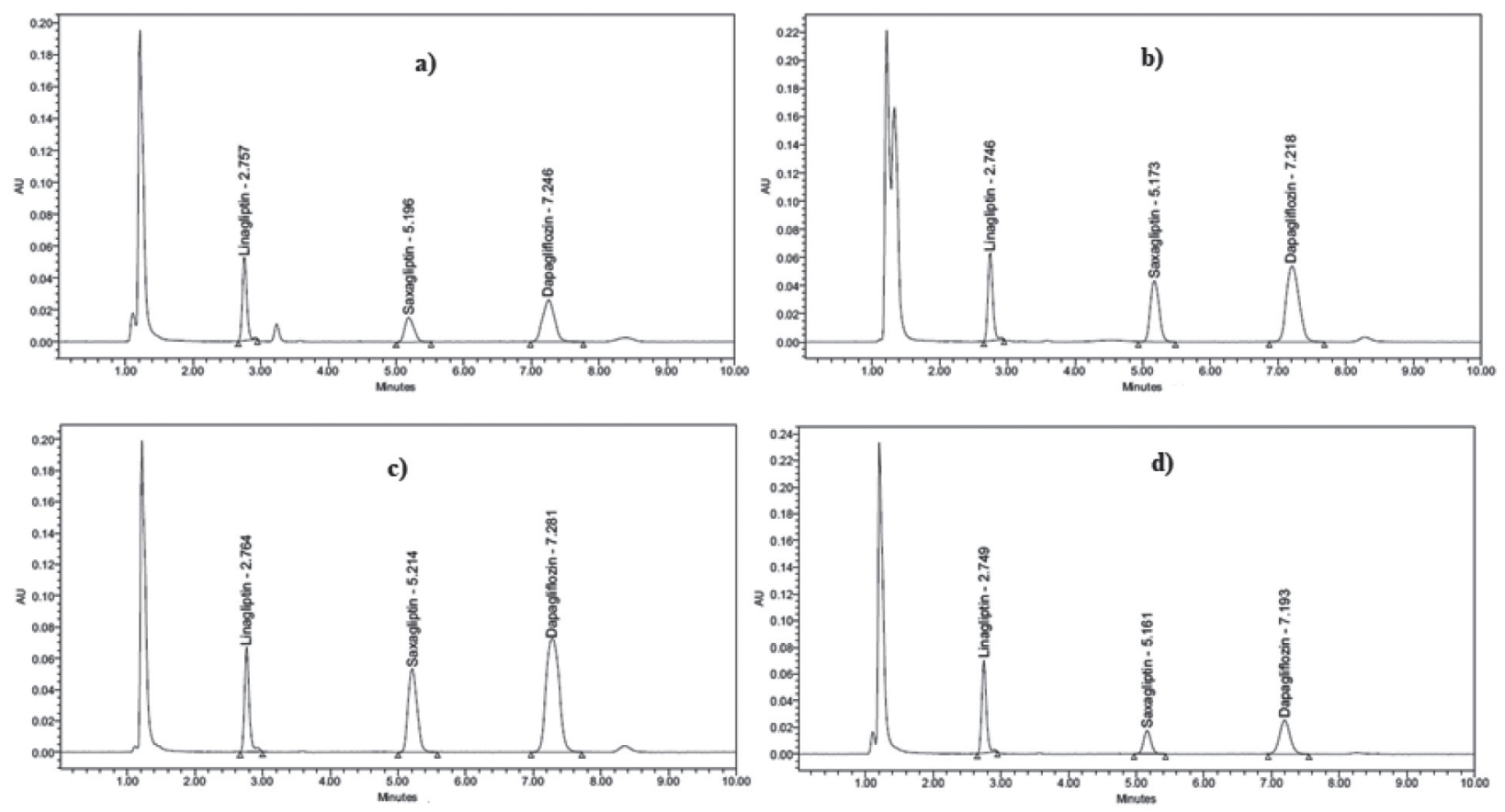

Figure 3. Chromatograms of a) low quality control sample, b) middle quality control sample, c) high quality control sample, and d) lower limit quality control sample

\begin{tabular}{|c|c|c|c|}
\hline Analyte & $\begin{array}{l}\text { Nominal concentration } \\
(\mu \mathrm{g} / \mathrm{mL})\end{array}$ & \% Recovery & $\%$ RSD* \\
\hline \multirow{4}{*}{ Saxagliptin } & 0.04 (LQC) & 76.40 & 1.58 \\
\hline & $0.20(\mathrm{MQC})$ & 88.07 & 0.21 \\
\hline & $0.4(\mathrm{HQC})$ & 71.60 & 2.08 \\
\hline & Across mean & 78.689 & 8.469 \\
\hline \multirow{4}{*}{ Dapagliflozin } & 0.2 (LQC) & 82.82 & 0.17 \\
\hline & $1.0(\mathrm{MQC})$ & 78.76 & 0.93 \\
\hline & $1.6(\mathrm{HQC})$ & 82.79 & 0.96 \\
\hline & Across mean & 81.458 & 2.86 \\
\hline $\begin{array}{l}\text { Internal } \\
\text { standard }\end{array}$ & 0.1 & 82.22 & 0.46 \\
\hline
\end{tabular}

LQC: Low quality control, MQC: Medium quality control, HQC: High quality control, RSD: Relative standard deviation

of the same make. The results of the ruggedness study were found to be within acceptable limits, proving no significant analyst-to-analyst and instrument-to-instrument variation and hence the ruggedness of the method. The results are presented in Table 4.

\section{Stability}

The stability of the analytes in human plasma was assessed by analysis of six replicates of quality control samples at low and high concentration levels at room temperature over $24 \mathrm{~h}$ (benchtop stability). The measured concentrations were compared with those of freshly prepared and processed samples. The results obtained indicated that the two drugs saxagliptin and

\begin{tabular}{|c|c|c|c|c|c|c|c|c|}
\hline \multirow{2}{*}{ Parameter } & \multicolumn{4}{|c|}{ Saxagliptin } & \multicolumn{4}{|c|}{ Dapagliflozin } \\
\hline & $\mathrm{HQC}$ & $M Q C$ & LQC & LLOQ & $\mathrm{HQC}$ & $M Q C$ & LQC & LLOQ \\
\hline \multicolumn{9}{|c|}{ Different column } \\
\hline Mean & 0.401 & 0.195 & 0.039 & 0.010 & 1.597 & 1.008 & 0.198 & 0.050 \\
\hline SD & 0.027 & 0.011 & 0.001 & 0.008 & 0.119 & 0.052 & 0.011 & 0.004 \\
\hline$\%$ CV & 6.66 & 5.38 & 2.98 & 7.66 & 7.47 & 5.12 & 5.31 & 7.90 \\
\hline $\begin{array}{l}\% \text { Mean } \\
\text { accuracy }\end{array}$ & 100.17 & 97.50 & 97.92 & 98.33 & 99.79 & 100.77 & 98.83 & 100.00 \\
\hline \multicolumn{9}{|c|}{ Different analyst } \\
\hline Mean & 0.404 & 0.195 & 0.040 & 0.010 & 1.614 & 1.006 & 0.201 & 0.049 \\
\hline SD & 0.018 & 0.0164 & 0.002 & 0.001 & 0.070 & 0.071 & 0.009 & 0.002 \\
\hline$\% \mathrm{CV}$ & 4.39 & 8.43 & 3.84 & 8.94 & 4.35 & 7.02 & 4.45 & 4.71 \\
\hline Mean & 101.08 & 97.50 & 98.75 & 100.0 & 100.8 & 100.6 & 100.3 & 98.33 \\
\hline
\end{tabular}

LQC: Low quality control, MQC: Medium quality control, HQC: High quality control, SD: Standard deviation, CV: Coefficient of variation, LLOQ: Lower limit of quantification

dapagliflozin were stable for at least $24 \mathrm{~h}$ in human plasma when retained at room temperature. On the other hand, the results obtained for quality control samples subjected to longterm storage at $-28^{\circ} \mathrm{C}$ for 37 days and at $-80^{\circ} \mathrm{C}$ indicate the stability of analytes in human plasma. In contrast, the freezethaw stability determined by using LLOQ, LQC, MQC, and HQC level of samples also indicated the stability of analytes in human plasma. The results obtained are compiled in Table 5. 
Table 5. Stability data of saxagliptin and dapagliflozin in human plasma

\begin{tabular}{|c|c|c|c|c|}
\hline \multirow{2}{*}{ Storage conditions } & \multicolumn{2}{|l|}{ Saxagliptin } & \multicolumn{2}{|l|}{ Dapagliflozin } \\
\hline & LQC & $\mathrm{HQC}$ & LQC & $\mathrm{HQC}$ \\
\hline \multicolumn{5}{|l|}{ Bench-top stability } \\
\hline Mean calculated concentration $(\mu \mathrm{g} / \mathrm{mL}) \pm \mathrm{SD}$ & $0.0402 \pm 0.0017$ & $0.4033 \pm 0.0175$ & $0.1952 \pm 0.0111$ & $1.5783 \pm 0.0686$ \\
\hline$\% \mathrm{CV}$ & 4.29 & 4.34 & 5.67 & 4.35 \\
\hline$\%$ Mean accuracy & 100.42 & 100.83 & 97.58 & 98.65 \\
\hline \multicolumn{5}{|l|}{ Freeze-thaw stability (after 3 cycles) } \\
\hline Mean calculated concentration $(\mu \mathrm{g} / \mathrm{mL}) \pm \mathrm{SD}$ & $0.0379 \pm 0.0023$ & $0.3998 \pm 0.0188$ & $0.1903 \pm 0.0273$ & $1.5639 \pm 0.0904$ \\
\hline$\% \mathrm{CV}$ & 3.76 & 8.56 & 7.34 & 4.35 \\
\hline$\%$ Mean accuracy & 98.78 & 99.47 & 97.89 & 99.90 \\
\hline \multicolumn{5}{|l|}{ Stability at $-28^{\circ} \mathrm{C}$ (long-term stability) } \\
\hline Mean calculated concentration $(\mu \mathrm{g} / \mathrm{mL}) \pm \mathrm{SD}$ & $0.0398 \pm 0.0012$ & $0.4013 \pm 0.01328$ & $0.1920 \pm 0.01279$ & $1.6110 \pm 0.0718$ \\
\hline$\% \mathrm{CV}$ & 2.93 & 3.31 & 6.66 & 4.46 \\
\hline$\%$ Mean accuracy & 99.58 & 100.33 & 96.00 & 100.69 \\
\hline \multicolumn{5}{|l|}{ Stability at $-80^{\circ} \mathrm{C}$ (long-term stability) } \\
\hline Mean calculated concentration $(\mu \mathrm{g} / \mathrm{mL}) \pm \mathrm{SD}$ & $0.0400 \pm 0.0015$ & $0.4018 \pm 0.0098$ & $0.1968 \pm 0.01347$ & $1.6120 \pm 0.0830$ \\
\hline$\% \mathrm{CV}$ & 3.87 & 2.43 & 6.84 & 5.15 \\
\hline$\%$ Mean accuracy & 100.00 & 100.46 & 98.42 & 100.80 \\
\hline
\end{tabular}

LQC: Low quality control, HQC: High quality control, SD: Standard deviation, CV: Coefficient of variation

\section{DISCUSSION}

Since there is no reported sensitive method for the estimation of saxagliptin and dapagliflozin in combination, the validated LC-UV method was developed for routine analysis in a biological matrix. Moreover, the available methods were developed to assess drugs either individually or in combination. Therefore, there is a need to develop an analytical method for the estimation of this combination. The current method aims to develop a simple, accurate, and reliable method for the simultaneous estimation of saxagliptin and dapagliflozin in human plasma. Good resolution and minimum tailing were achieved using this method. The method used simple singlestep protein precipitation with acetonitrile and provided good selectivity when tested for peak interference from endogenous sources by comparing the blank chromatogram with quality control samples. The retention times of the internal standard, saxagliptin, and dapagliflozin were found to be $2.746,5.173$, and $7.218 \mathrm{~min}$, respectively. The developed method proved to be rugged and had adequate recovery and no matrix effect. The recovery was determined by comparing the extracted sample with the unextracted samples at three quality control sample levels, i.e., $L Q C, M Q C$, and $L L O Q$. The results were found to be within acceptable limits. The linearity of the method was tested by developing an eight-point calibration curve that included all quality control sample concentrations. The linear range for saxagliptin and dapagliflozin was found to be 0.01 to $0.50 \mu \mathrm{g} / \mathrm{mL}$ and 0.05 to $2.00 \mu \mathrm{g} / \mathrm{mL}$, respectively. The regression coefficient for saxagliptin and dapagliflozin was 0.996 and 0.998 , respectively. The linear range and statistical parameters prove that the developed method is more sensitive than the reported LC coupled with a PDA detector. Using the stability studies, it was found that the analytes were stable in plasma throughout the analysis period. The stability data were built by comparing the stability samples with freshly prepared samples. On the other hand, long-term stability was established by subjecting quality control samples to $-28^{\circ} \mathrm{C}$ for 37 days and to $-80^{\circ} \mathrm{C}$. The results obtained indicate that the method is sensitive, reliable, and cost-effective. Furthermore, the method can be made applicable to pharmacokinetic estimation.

\section{CONCLUSIONS}

The proposed method for the estimation of a saxagliptin and dapagliflozin binary mixture in human plasma is simple, accurate, and reliable. The single-step protein precipitation, short runtime of $10 \mathrm{~min}$, and isocratic elution make the method economical and suitable for the analysis of a large number of samples. The method has been validated as per the requirements of the USFDA. It can therefore be concluded that the method is suitable for the routine quantification of saxagliptin and dapagliflozin in human plasma.

\section{ACKNOWLEDGEMENT}

The authors are grateful to V.V. Institute of Pharmaceutical Sciences, Gudlavalleru, for providing the facilities to carry out this work.

Conflict of Interest: No conflict of interest was declared by the authors. 


\section{REFERENCES}

1. Williams DM, Stephens JW. Combination Therapy with Saxagliptin and Dapagliflozin for the Treatment of Type 2 diabetes. Expert Opin Pharmacother. 2015;16:2373-2379.

2. FDA Approves Once-Daily Qtern (dapagliflozin and saxagliptin) Tablets for Adults with Type-2 Diabetes [Internet]. Drugs.com. Available from: https://www.drugs.com/newdrugs/fda-approves-once-daily-qterndapagliflozin-saxagliptin-adults-type-2-diabetes-4493.html.

3. Manasa S, Dhanalakshmi K, Nagarjunareddy G, Sreenivasa S. Development and Validation of a RP-HPLC Method for the Estimation of Dapagliflozin in API. Int J Pharm Sci. 2014;5:5394-5397.

4. Shyamala M, Nidhi B, Kavitha M, Pooja Sharma JV. Validated RP-HPLC Method for Simultaneous Estimation of Metformin Hydrochloride and Dapagliflozin in Tablet Dosage Form. AJBPR. 2015;2:109-113.

5. Dapagliflozin [Internet]. National Center for Biotechnology Information. PubChem Compound Database. U.S. National Library of Medicine; Available from: https://pubchem.ncbi.nlm.nih.gov/compound/ Dapagliflozin (accessed May 23, 2017).

6. Dave DJ. Saxagliptin: A dipeptidyl peptidase-4 inhibitor in the treatment of type 2 diabetes mellitus. J Pharmacol Pharmacother. 2011;2:230235.

7. Saxagliptin [Internet]. National Center for Biotechnology Information. PubChem Compound Database; U.S. National Library of Medicine; Available from:https://pubchem.ncbi.nlm.nih.gov/compound/Saxaglitin (accessed May 23, 2017).

8. Gumieniczek A, Berecka A. Analytical tools for determination of new oral antidiabetic drugs, glitazones, gliptins, gliflozins and glinides, in bulk materials, pharmaceuticals and biological samples. Open Chem. 2016;14:215-242.

9. El-Bagary RI, Elkady EF, Ayoub BM. Spectrophotometric Methods Based on Charge Transfer Complexation Reactions for the Determination of Saxagliptin in Bulk and Pharmaceutical Preparation. Int J Biomed Sci. 2012;8:204-208.

10. Aubry AF, Gu H, Magnier R, Morgan L, Xu X, Tirmenstein M, Wang B, Deng Y, Cai J, Couerbe P, Arnold M. Validated LC-MS/MS Methods for the Determination of Dapagliflozin, a Sodium-Glucose Co-Transporter 2 Inhibitor in Normal and ZDF Rat Plasma. Bioanalysis. 2010;2:20012009.

11. Batta N, Pilli N, Derangula V, Vurimindi H, Damaramadugu R, Yejella R. A Rapid and Sensitive LC-MS/MS Assay for the Determination of Saxagliptin and its Active Metabolite 5-Hydroxy Saxagliptin in Human Plasma and its application to a pharmacokinetic study. Drug Res. 2014:65:133-140.

12. Pawanjeet JC, Balaji M, Srinivasarao V, Ramakrishna K, Apparao KM. Devolpment and validation of simple stability indicating RP-HPLC method for analysis of saxagliptin and its forced degradation impurities in bulk drug and pharmaceutical dosage form. Int J Res Dev Pharm L Sci. 2014;3:993-1003.

13. Scheeren LE, Marcolino AIP, Adams AIH, Rolim CMB. Stability indicating RP-LC-PDA method for the quantitative analysis of saxagliptin in pharmaceutical dosage form. Braz J Pharm Sci. 2015;51:461-466.
14. Islam S, Hossain T, Kundu SK, Halim A, Rafiquzzaman. Development and validation of RP-HPLC method for determination of saxagliptin hydrochloride in bulk and tablet dosage form. World Journal of Pharmaceutical Research. 2016;5:107-119.

15. Daswadkar SC, Roy MA, Walode SG, Mahendra Kumar CB. Quality by design approach for the development and validation of saxagliptin by RP-HPLC with application to formulated forms. Int J Pharm Sci. 2016;7:1670-1677.

16. Andac SC, Alp AR. A Validated HighPerformance Liquid Chromatography Method for the Determination of Saxagliptin and Metformin in Bulk, a Stability Indicating Study. J Anal Bioanal Tech. 2014;12:1-5.

17. Sanagapati M, Dhanalakshmi K, Nagarjunareddy G, Sreenivasa S. Development and validation of a RP-HPLC method for the estimation of dapagliflozin in API. Int J Pharm Sci. 2014;5:5394-5397.

18. Debata J, Kumar S, Jha SK, Khan A. A New RP-HPLC method development and validation of dapagliflozin in bulk and tablet dosage form. Int J Drug Dev Res. 2017;9:48-51.

19. Jeyabaskaran M, Rambabu C, Dhanalakshmi B. RP-HPLC method development and validation of dapagliflozin in bulk and tablet formulation. IJPAR. 2013;2:221-226.

20. Kalaichelvi R, Jayachandran E. Validated spectroscopic method for estimation of saxagliptin in pure and from tablet formulation. Int $\mathrm{J}$ Pharm Pharm Sci. 2011;3:179-180.

21. Moneeb SM. Spectrophotometric and spectrofluorimetric methods for the determination of saxagliptin and vildagliptin in bulk and pharmaceutical preparations. Bulletin of Faculty of Pharmacy Cairo University. 2013;51:139-150.

22. Prasad PBN, Satyanaryana K, Krishnamohan G. Development and Validation of a Method for Simultaneous Determination of Metformin and Saxagliptin in a Formulation by RP-HPLC. Am J of Anal Chem. 2015;6:841-850.

23. Merey HA, Ramadan NK, Diab SS, Moustafa AA. Chromatographic methods for the simultaneous determination of binary mixture of Saxagliptin $\mathrm{HCl}$ and Metformin $\mathrm{HCl}$. Bulletin of Facult Pharmacy Cairo Univiversty. 2017;55:311-317.

24. Thangabalan B, Srisowmya P, Manohar Babu S. Method development and validation for simultaneous estimation of saxagliptin and metformin in tablet dosage form by RP-HPLC method. IJPAR. 2014:3:363-369.

25. Yunoos M, Gowri SD. Stability indicating quantitative RP-HPLC method development and validation for simultaneous determination of metformin hydrochloride and saxagliptin in bulk and combined tablet dosage form. J Chem Pharm Res. 2015;7:346-355.

26. Yunoos M, Gowrisankar D. A validated stability indicating highperformance liquid chromatographic method for simultaneous determination of metformin hcl and dapagliflozin in bulk drug and tablet dosage form. Asian J Pharm Clin Res. 2015;8:320-326.

27. Guidance for Industry. Bioanalytical Method Validation for human studies. U. S. Department of Health and Human Services Food and Drug Administration, Center for Drug Evaluation and Research (CDER); 2013:1-23. 